\title{
Inclusive Education in the 21st Century: Parameters and Opportunities for Learners with Special Needs
}

\author{
Udeme Samuel Jacob \\ Angela Nneka Olisaemeka
}

Department of Special Education, Faculty of Education, University Of Ibadan, Ibadan, Oyo State

doi: 10.19044/esj.2016.v12n10p188 URL:http://dx.doi.org/10.19044/esj.2016.v12n10p188

\begin{abstract}
This paper examined parameters and opportunities for learners with special educational needs in an effective inclusive education as it relates to $21^{\text {st }}$ century. It differentiated inclusive education from mainstreaming and integration and went further give a comprehensive meaning to the term inclusive education. Some of the benefits of this inclusive education are multicultural learning environment, socialization and the development of the child. Parameters identified for effective inclusive education are placing the child in age appropriate grade place, no special classes or schools and cooperative learning practiced where teachers can share ideas for improvement of the educational system. Conclusion was made on the need for inclusive education.
\end{abstract}

Keywords: Inclusive Education, Parameters, Opportunities, Special Needs

\section{Introduction}

Children with disability deserve equal access to quality education which enable them develop into useful member of the society and contribute to the economic growth of their immediate community irrespective of their areas of special needs. Special needs children include all children who, for whatever reasons, are failing to benefit from school (UNESCO Report, 1994). Young people with disabilities otherwise known as special needs are among the poorest and most marginalized of the world's youth. Estimates suggest that there are between 180 and 220 million youth with disabilities worldwide, and nearly 80 percent of them live in developing countries (United Nations, Division for Social Policy and Development, 2011). This might be due to their inability to make economic contribution to the society and earn a meaningful leaving wage but are made to depend on others for alms through begging. 
It is estimated that there will be at least 200 million people (at least 18 million people with disabilities) displaced by climate events by 2050 (Skoufias Rabassa \& Olivier, 2011), they are in need of modification of the learning environment in one form or the other to suit their learning. Although in Nigeria, today special educators, parents of students with disabilities, policy-makers and other stakeholders continue to debate the benefits and challenges of inclusive education (Ajuwon, 2008). Oyewo (1999) remarked that the growth of the human society depends almost entirely on the contributions of its members. Experts have suggested that an inclusive education should be encouraged by governments by way of providing infrastructure and other facilities that enhance learning, socialization and the overall development of children with disability (Chika, 2011). There is a growing recognition that including students with disabilities in general education can provide them with the opportunity to learn in natural, stimulating settings, which may also lead to increased acceptance and appreciation of differences (Ajuwon, 2008). This will be possible where the learning environment is stimulating and the teacher are adequately training on managing the different needs that comes with such learning environment

According to Osakwe (2010), the school systems now face increasing pressure to raise standards, develop social and personal skills, broaden curricula, pay greater attention to equal educational opportunities and prepare young people for rapidly changing world. Invariably, the modern trend all over the world is shifting towards addressing the educational plights of students with one form of disabilities or the other so as to better their life. It must be understood that in some developing countries like Nigeria, inclusive education is thought as an approach to serving children with disabilities within general education settings. Consequently the National Policy on Education in Nigeria states that Special Education is created as a formal special educational training given to people (children and adults) with special needs (Federal Government of Nigeria, 2004).

However, this is contrary to the international practice where inclusive education is seen "as a reform that supports and welcomes diversity amongst all learners" (UNESCO, 2001). Precisely, Inclusive Education (IE) insists that all children with special needs should be included in the traditional classroom to study with their non-disabled peers (Abosi, 2001) because socialization of these children will be done at this stage since they have opportunity of interacting with the regular learners. It is anchored on human rights, social justice and equity ideals and through it, segregatory practices are eliminated and students benefit from the socialization and educational processes (Lo, 2007). Inclusion is when students with disabilities receive their entire academic curriculum in the general education program. This is different from mainstreaming, which is when students with disabilities spend 
a portion of their school day in the general education program and a portion in a separate special education program (Idol, 1997).

\section{Inclusive Education}

Inclusion refers to the "full-time placement of children with mild, moderate and severe disabilities in regular classrooms" (Staub\& Peck, 1994/95). Inclusive education differs from previously held notions of "integration" and "mainstreaming", which tended to be concerned principally with disability and "special education needs" and implied accommodation of all categories of learners in the classroom (Wikipedia, the Free Encyclopedia, 2014). Inclusion is a step further in mainstreaming, as it presents a means "by which a school attempts to respond to all pupils as individuals, by reconsidering and structuring its curricular organization and provision, and allocating resources to enhance equality of opportunity and through this process, the school builds its capacity to accept all pupils from the local community who wish to attend, and in doing so, reduces the need to exclude pupils" (Sebba\&Sachdev, 1997).

Inclusive education is concerned with minimizing and removing barriers to access, participation and learning for all children, but especially for those who have been socially discriminated because of poverty, disability, gender, religion, ethnicity or any inequalities (UNESCO, 2006). According to the National Centre on Educational Restructuring and Inclusion (1995), inclusive education means: Providing to all students, including those with significant disabilities, equitable opportunities to receive effective educational services, with the needed supplementary aids and support services, in age appropriate classrooms, in order to prepare students for productive lives as full members of society.

Centre for Studies on Inclusive Education (2002) as cited in Okobah (2007) defines inclusive education as a programme for all children and young people with or without disabilities or difficulties learning together in ordinary pre-primary provisions, schools, colleges and universities with appropriate network. The aim of inclusive education is not to erase differences in children but to enable all children to belong to the same educational community (Knight, 1999), while at the same time eliminating social exclusion arising from attitudes and responses to diversity in race, social class, ethnicity, religion, gender and ability (Vitello and Mithaug, 1988 cited by Ainscow, 2004).

The goal of inclusive education as rightly observed by Knight (1999) is not to erase differences in children but to enable all children to belong to the same educational community. Kochlar, West and Taymans (2000) equally stated that inclusion in special education means that schools, classes and activities are scheduled for students with disabilities so that opportunities 
for their participation are maximized. UNESCO (2009), perceives it as a process of transforming schools and other centers of learning to accommodate all learners including boys and girls, learners from ethnic and linguistic minorities, rural populations, those infected and affected by HIV and AIDS, those with disabilities and difficulties in learning and as well provide learning opportunities for all. Accommodating such learners will in small way help in developing self-esteem needed to overcome obstacle that the disability would have posed to them.

\section{Parameters for Effective Inclusive Education}

A critical aspect of inclusive education for a special needs child is having the acceptance and friendship of classmates. This kind of support also aids in the progress of special children and helps them gain confidence within the school environment(Balasubramanian, 2012). There is need to document the number, characteristics and specific geographic location of students required to be in inclusive programs, the number of specialists who will support their instruction, the necessary amount of in-class and out-ofclass collaboration between special and general education teachers and guidance counselors, and the optimal type and extent of support from ancillary staff (Eskay, Ezegbe\&Anyanwu, 2013).

Giorcelli (1993) listed the following as principles of a properly planned and fully implemented inclusive education: appropriate age and grade placements; no special classes or schools; cooperative learning practiced; special education support given to regular education; and collaborative efforts needed to provide service to all who need them.Giangreco (1997) identified common features of schools where inclusive education is reported to be thriving. These features are: collaborative teamwork; a shared framework; family involvement; general educator ownership; clear role relationships among professionals; effective use of support staff; meaningful Individual Education Plans (IEPs) and procedures for evaluating effectiveness.

Standard and adequate supervision should be ensured so that these lofty but well intentioned introductions into the educational system will achieve its desired goals. The first important step is to change the discriminatory attitudes towards youth and adults who have disabilities which are as a result of superstitions about causation of disabilities (Ajuwon\& Sykes, 1988).Teachers' attitudes have been found to influence the process and the outcome of inclusion to a great extent (Avramidis, Bayliss\&Burdenet, 2000). Zambelli and Bonni (2004) stated that two factors are important in the formation of positive attitudes towards inclusion, namely, increased knowledge and information about school inclusion and disabilities. 
Inclusive schools have to be well-equipped in all aspects to cater and deliver quality education for all children. This includes having a balanced curriculum that is appropriate for all categories of children, teachers who have the ability to handle the individual needs within the classroom and thereby promote an environment where personal development, social skills and student participation are strongly encouraged (Balasubramanian, 2012).

\section{Benefits of Inclusive Education}

Salend (2005); Smith, Palloway, Patton and Dowdy (2006)summarize the advantages of inclusion: Research indicates that at the elementary school level, students with disabilities who are included in general education curricula can benefit socially and academically without facing the stigma of segregated or pull-out classrooms. Standards for behavior and instruction are higher, and students with classifications have more opportunity to reach higher standards and become independent learners. It is also believed that integration into the mainstream enables students with disabilities to benefit from the stimulation of mixing with relatively more able students and to have the opportunity to observe higher models of social and academic behaviour (Elkins, 1998).

Inclusion has academic and social benefits for all students, whether with or without disabilities, such as increased communication and social interaction opportunities, age-appropriate models of behaviour skills, more active participation in the school community, individualized education goals, as well as access to the rich core curriculum (Grenot-ScheyerJubala, Bishop \&Cootset, 1996).Inclusion recognizes that all students are learners who benefit from a meaningful, challenging, and appropriate curriculum and differentiated instruction techniques that address their unique strengths and needs (Salend, 2005).

Studies also indicate that students without disabilities can benefit from inclusive settings. Findings reveal academic performance is equal or superior to comparative groups of students educated in a non-inclusive setting, and students with severe disabilities do not significantly limit or interrupt instructional time for nondisabled peers in inclusive settings. Friendships and awareness of diversity are also benefits of the inclusive classroom for individuals without disabilities (Vollmer \& Vollmer, 2002).

On an interpersonal level, inclusive education allows children to develop friendships with their peers and feel less social tension about their disabilities. Some people believe that children who are placed in standard classroom environments generally have higher self-esteem than children who are isolated to different classrooms simply because they have special needs (California Special Needs Law Group, 2009). The implementation of 
inclusive education system as against segregated education system has a number of advantages. These include the fact that it:

- encourages students without disabilities to accept and tolerate children with special needs;

- $\quad$ improve the sociability of children with special needs;

- $\quad$ reduces the cost of providing separate education for children with and without special needs;

- $\quad$ eliminates or reduces social stigma associated with people with special needs;

- $\quad$ provides an all-round development of the child with and without special needs; and

- $\quad$ enables children without special needs develop positive attitude towards people with handicapping conditions (Gesinde, $\mathrm{n}$ d).

\section{Recommendation}

The following are recommendations made:

- $\quad$ Teachers should be trained on what their roles should be in effective implementation of inclusive education

- $\quad$ The curriculum should be modify to accommodate learners with special needs different learning style so as to achieve the needed change

- Learners in the inclusive educational system should be allowed to learn at their own pace as this will lead to achieving learning objectives

- $\quad$ Resource teachers trained in handling children with special needed should employed and motivated to embrace this system of education

\section{Conclusion}

There are several barriers for providing education to special children in a regular classroom such as all forms of superstitious beliefs about disabilities that have for so long inhibited involvement with people with disabilities in education and the community. When this is done, it will enable children with special needs to have a distinctive experience by undergoing inclusive education along with normal, non-disabled classmates. Obstacles to inclusive education can be overcome by creating awareness on what inclusion is and the benefits to the society, schools having the resources and the ability to re-structure their curriculum to cater to all types of students, by recruiting teachers who have the skills and proficiency to meet varying demands within the classroom and by having the support of family. The bottom line of this type of education for students with disabilities should be equitable access to opportunities that will guarantee successful outcomes in education, employment and community integration. 


\section{References:}

Abosi, C. O. (2001) Thoughts on an Action Plan for the Development of Inclusive Education in Africa in Stout, K. S. (2001) Inclusive Education, Updated by Huston, J. (2007).

Ajuwon, P. M. (2008) Inclusive Education for Students With Disabilities in Nigeria: Benefits, Challenges and Policy Implications. International Journal of Special Education, 11-17.

Ajuwon, P. M. \& Sykes K. C. (1988). Community involvement with the disabled: Some theoretical and practical considerations. Ife Journal of Theory and Research in Education.Vol. 1, No. 1.5-11.

Ainscow, M. (2004). Developing Inclusive Education Systems: What Are the Levers for Change? Manchester: The University of Manchester.

Avramidis E, Bayliss P, Burden R (2000). A survey into mainstream teachers' attitudes towards the inclusion of children with special education needs in the ordinary school in one local education authority. Educational Psychology; 20(2): 191-212.

Balasubramanian, A (2012) Inclusive education for children with special needs The Hindu Retrieved from http://www.thehindu.com/todays-paper/tpfeatures/tp-opportunities/inclusive-education-for-children-with-specialneeds/article3959638.ece June, 2015

California Special Needs Law Group (2009) The Concept of Inclusive Education and Understanding Children with Special Needs. Retrieved from http://www.csnlg.com/blog/the-concept-of-inclusive-education-andunderstanding-children-with-special-needs/ June, 2015

Chika M. (2011) Case for Inclusive Education In Nigeria Retrieved from http://whatsupnigeria.blogspot.com/2011/05/case-for-inclusive-education-innigeria.html June 2015

Elkins J (1998). The school context. In A. Ashman \& J. Elkins (Eds.), Educating children with special needs (3rd ed., pp. 67 - 101). Sydney: Prentice Hall.

Eskay, M., Ezegbe, B. N \&Anyanwu J (2013) The American No Child Left Behind Act: Implications for theNigerian School System.Journal of Education and Practice 4 (13); 176 - 180

Federal Government of Nigeria (2004).National Policy on Education. Lagos: NERDC Press.

Gesinde M. A (2010) Inclusive Education: Problems, and Remedies 102 105 in Theo- Ajobiewe, Adebiyi B. A and Olubela O. L (2010) Professional Standard of Practice for Special Educators Retrieved from http://eprints.covenantuniversity.edu.ng/632/1/Inclusive\%20Education.\%20P roblems\%2C\%20And\%20Remedies.pdf June, 2015 
Giangreco, M. F. (1997) 'Key lessons learned about inclusive education: summary of the 1996 Schonell Memorial Lecture', International Journal of Disability, Development and Education, 44(3): 193-206.

Grenot-Scheyer M, Jubala KA, Bishop KD, Coots JJ (1996).The inclusive classroom. Westminster: Teacher Created Materials, Inc.

Idol, L. (1997).Creating collaborative and inclusive schools. Austin, TX: PRO-ED. Phelps, L.A (2003). High schools with authentic and inclusive learning practices:

Knight B.A. (1999); "Towards Inclusion of Students vvith Special Educational Needs in the Regular Classroom."British Journal of Learning Support. 14 (1), 3-7.

Kochhar C. A., West L. L. and Taymans J. M. (2000); Successful Inclusion. Practical Strategies for a Shared Responsibility. Upper Saddle River, N.J. Prentice Hall.

Lo, L. N.-K. (2007). The sustainable development of inclusive education. Chinese Education Society, 40(4), 44-62.

National Centre on Educational Restructuring and Inclusion (1995). National Study of Inclusive Education. New York: The City University of New York. Okobah U. M. (2007); "The What and How of Inclusive Education in the UBE." E. D. Ozoji and J. M. Okuoyibo (Eds.), The Practice and Future of Special Needs Education in Nigeria (pp.37 - 51). Jos: Dcka Nigeria.

Osakwe, R. N. 2010. "Education for People with Special Needs in Nigeria: Challenges and Way Forward” in M. I. Atinmo, J. B. Babalola, O. A. Moronkola and A. I. Atanda.Eds. Education for Sustainable Development.Faculty of Education, University of Ibadan.33-43.

Oyewo, N. A. 1999. “Coping with Disability in the Next Millennium”. A Lecture Delivered at the Federal College of Education (Special), Oyo.

Salend, S. J. (2005). Creating inclusive classrooms: Effective and reflective practices for all students (Sth ed.). Columbus, OH: Merrill/Prentice Hall Sebba J, Sachdev D. What works in inclusive education.Barnardo's, Essex, 1997.

Skoufias, E., Rabassa, M. \& Olivieri, O. (2011) the Poverty Impacts of Climate Change: A Review of the Evidence, Policy Research Working Paper 5622, and the World Bank.

Smith, T.E.C., Polloway, E.A., Patton, J.R., \& Dowdy, C.A. (2006). Teaching students with special needs in inclusive settings, (revised IDEA edition). Boston: Allyn\& Bacon,

Staub D, Peck C. (1994/95) What are the outcomes for nondisabled students? Educational Leadership 52 (4) 36-40. Retrieved from http://staff.pausd.org/ areyes/B_Park_Inclusion/Resources/Resources_files/I nclusion\%20Research.pdf

UNESCO (2001). Open File on Inclusive Education. Paris: UNESCO. 
UNESCO.(2009). New UNESCO Guidelines on Inclusive Education. Paris: UNESCO.

United Nations, Division for Social Policy and Development, (2011) Fact sheet on Youth with Disabilities, available at: http://social.un.org/youthyear/docs/Fact\%20sheet\%20youth\%20with\%20disa bilities.pdf

Wikipedia, the Free Encyclopedia (2014).Inclusion (Education). http://en.wikipedia.org/wiki/Inclusion_(education)

Vollmer R, Vollmer, J R (2002) Engaging Students in the Inclusive Classroom: Research and Theoretical Underpinning Retrieved from http://www.sagepub.com/upm-data/39528_Pages_from_Green_ch1.pdf June, 2015

Zambelli F, Bonni R (2004). Beliefs of teachers in Italian schools concerning the inclusion of disabled students: A Q-sort analysis. European Journal of Special Needs Education; 19(3): 351-364. 